\title{
Determining The Optimum Inventory Of Mujaerr Using The Newsboy Method (Case Study At Pt. Xyz)
}

\section{Menentukan Jumlah Persediaan Optimum Pada Ikan Mujaerr MenggunakanMetode Newsboy (Studi Kasus Pada Pt. Xyz)}

\author{
Pungky Suherman ${ }^{1}$, Ribangun Bamban Jakaria ${ }^{2}$ \\ Program Studi Teknik Industri, Fakultas Sains dan Teknologi, Universitas Muhammadiyah Sidoarjo \\ pungkysuherman1993@gmail.com
}

\begin{abstract}
Tilapia fish is a freshwater fish commodity that has quite a lot of nutritional content so that there are many devotees. PT. XYZ provides an adequate supply of tilapia fish, but there are many complaints from customers about the availability of this fish so they are demanded to continue conduct an evaluation of the fish stock. the fishmonger must decide how much fish to buy from the supplier. If the fish seller buys too much fish and it doesn't sell out on that day, then the large number of fish that are not sold has no value on that day. Conversely, if the fish seller buys too little fish, then the seller fish have lost the opportunity to get a bigger profit. This study aims to optimize the supply of mujaer fish. The method in research using the newsboy method, data collection methods used are by using observation, interviews and data processing. You will know the amount of fish stock for the day Monday to Friday as much as $3000 \mathrm{~kg}$, this calculation is based on the results of data patterns, trend analysis and the average fish sold, it can be concluded that Monday-Friday supplies can generate optimum profit.
\end{abstract}

Keywords - Tilapia Fish, Optimum Inventory, Newsboy Method

\begin{abstract}
Abstrak. Ikan mujair merupakan komoditas ikan air tawar yang memiliki kandungan gizi yang cukup banyak sehingga banyak peminatnya. PT. XYZ menyediakan cukup pasokan ikan mujaIr, akan tetapi banyak keluhan dari pelanggan terhadap ketersediaan ikan tersebut sehingga dituntut untuk terus melakukan evaluasi terhadap persediaan ikan tersebut. penjual ikan harus memutuskan berapa banyak ikan yang harus dibeli dari pemasok. Jika penjual ikan membeli ikan terlalu banyak dan tidak habis di jual pada hari itu, maka banyaknya ikan yang tidak terjual tidak memiliki nilai pada hari itu. Sebaliknya jika penjual ikan membeli ikan terlalu sedikit, maka penjual ikan telah kehilangan kesempatan untuk mendapatkan keuntungan yang lebih besar. Penelitian ini bertujuan untuk mengoptimalkan persediaan ikan mujaer. Metode pada penelitian menggunakan metode newsboy, metode pengumpulan data yang digunakan adalah dengan menggunakan observasi, wawancara serta pengolahan data. Diketahui jumlah persediaan ikan untuk hari senin sampai jumat sebanyak 3000kg, perhitungan ini berdasarkan hasil dari pola data, trend analysis dan rata-rata ikan yang terjual bisa disimpulkan bahwa persediaan dihari senin- jum'at dapat menghasilkan keuntungan yang optimum.
\end{abstract}

Kata Kunci - Ikan Mujaer, Persediaan Optimum, Metode Newsboy

\section{Pendahuluan}

Potensi populasi ikan di Indonesia sangat besar baik di darat maupun laut. Sumberdaya laut khususnya ikan dapat dimanfaatkan sebagai sumber protein hewani yang bernilai gizi tinggi sehingga bermanfaat bagi penduduk. Ikan nila merupakan salah satu ikan yang sering disantap. Ikan nila memiliki prospek komersial yang bagus. Ikan besar ini tergolong ikan air tawar, karena kandungan proteinnya yang tinggi, rasanya yang enak dan harga yang cukup terjangkau, permintaan belakangan ini semakin meningkat.Bandingkan dengan sumber protein hewani lainnya (seperti daging sapi). Salah satu tantangan yang dihadapi PT. XYZ adalah masalah manajemen persediaan, sehingga PT. XYZ menghadapi kondisi jalan untuk mencapai tujuan. Hal ini penting dilakukan agar biaya dapat ditekan seminimal mungkin dan proses dapat berjalan dengan lancar.

Pengambilan stok ikan dapat dikategorikan dalam pengendalian persediaan. Dalam penelitian ini, model yang digunakan dalam pengendalian persediaan adalah model newsboy. Model newsboy adalah model classics yang digunakan untuk fase pengendalian persediaan (inventory) yang dilakukan di PT. XYZ. Dengan itu sangat penting adanya perencanaan dan perancangan dalam menentukan jumlah persediaan optimum pada persediaan ikan 
mujair dengan metode Newsboy. Penelitian ini diharapkan bisa menentukan jumlah optimum persediaan ikan mujair dalam satu periode dengan metode newsboy sehingga PT. XYZ juga mendapatkan keuntungan yang optimum.

Pada penelitian yang lain menyebutkan metode newsboy sangat tepat jika digunakan untuk mencari persediaan yang optimum dikarenakan perencanaan produksi dan pengendalian terhadap bahan baku agar tidak terjadi stockout. Model Newsboy adalah model stokastik yang mempertimbangkan adanya faktor ketidakpastian dalam jumlah permintaan setiap periode produks [1]i. Sehingga model newsboy sangat cocok untuk menyelesaikan permasalahan tersebut.

\section{METODE}

Metode penelitian menggunakan 3 teknik pengumpulan data, diantaranya adalah wawancara, observasi dan studi dokumen. Wawancara merupakan sebuah teknik pengumpulan data dengan cara melakukan innteraksi atau perbincangan secara tatap muka dengan narasumber terkait untuk mendaptkan informasi mengenai data yang dicari [2]. Selain itu wawaara berfungsi untuk memperoleh penjelasan atau suatu pemahaman mengenai suatu fakta yang berkembang di kalangan petani tambak di wilayah objek penelitian dan sekaligus untuk mengetahui kendalakendala yang terjadi [3]. Obervasi yang digunakan adalah observasi non partisipan yaitu pengamatan yang dilakukan dengan cara peneliti tidak terlibat langsung dalam proses terebut dengaan kata lain hanya sebagai pengamat independen yang akan melihat atau mengamati, mencatat serta mempelajari data yang ditemukan [2] Sedangkan studi dokumen adalah peneliti mengambil data dari perusahaan untuk selanjutnya diolah dengan tujuan agar analisa yang dilaukan semakin tajam [4].

Penelitian dilakukan di Jl. Tambak Cemandi No.358, Dusun Gisiksemanggi, Banjar Kemuning, Kec. Sedati, Kabupaten Sidoarjo, Jawa Timur 61253, dilakukan pada Bulan Februari 2020 sampai dengan data yang diperluukan sudah terpenuhi. Target yang diinginkan yaitu berupa terpenuhinya data ikan yang dipasok dan terjual sehingga dapat dilakukan proses optimalisasi. 
Procedia of Engineering and Life Science Vol. 1. No. 2 June 2021

Seminar Nasional \& Call Paper Fakultas Sains dan Teknologi (SENASAINS $2^{\text {nd }}$ )

Universitas Muhammadiyah Sidoarjo

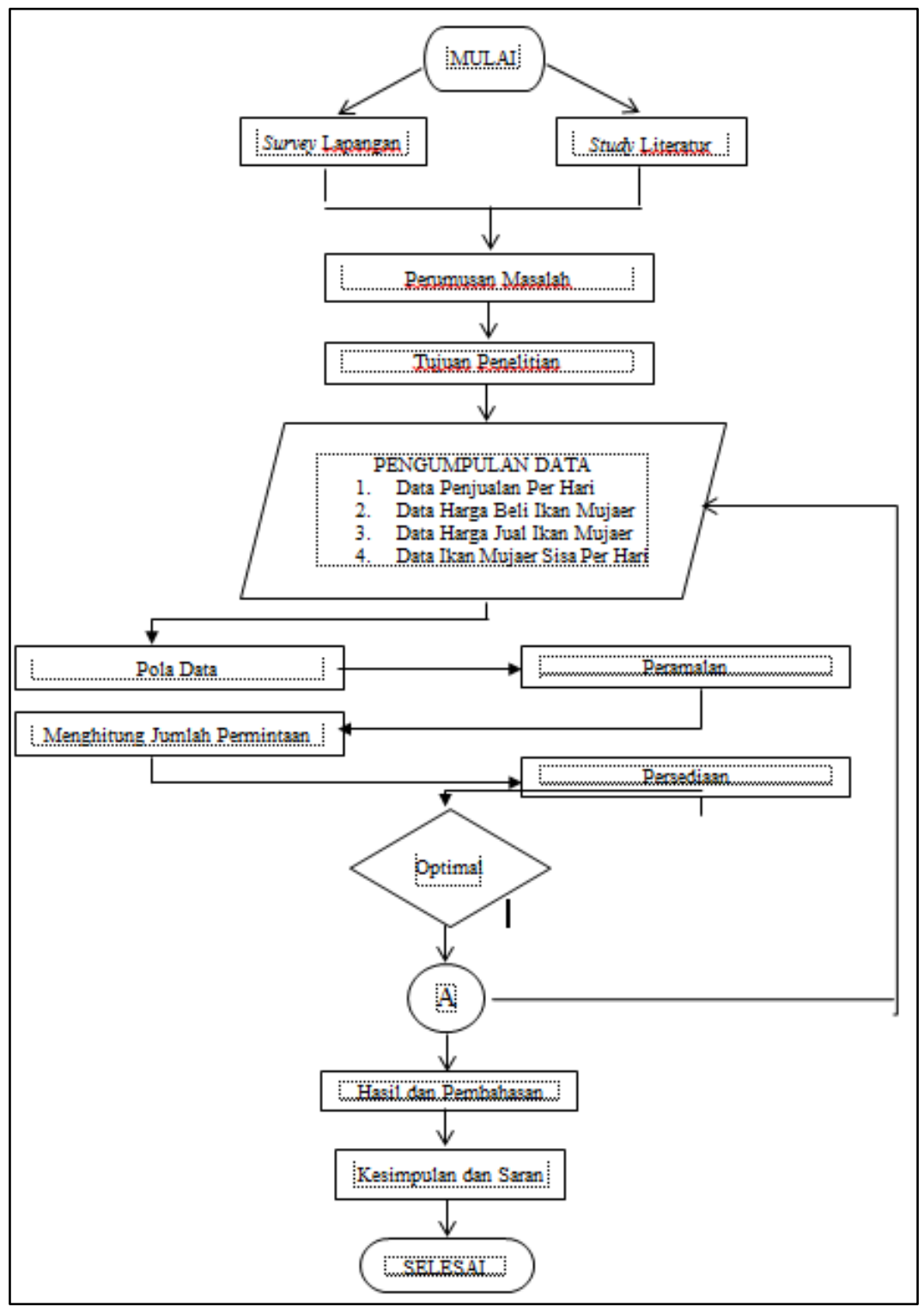

Gambar 1 flowchart Penelitian

\section{Hasilddan Pembahasan}

Data yang didapat antara lain harga beli (c), harga jual jam 7 pagi (s), harga jual jam 8 pagi (x), harga jual jam 9 pagi (v), dan data penjualan ikan perhari.

\section{A. Pengumpulan Data}

Data Penjualan

Tabel 1 Data Penjualan

\begin{tabular}{|c|c|c|c|c|c|c|c|}
\hline No & Sabtu & Minggu & Senin & Selasa & Rabu & Kamis & Jumat \\
\hline 1 & 2577 & 2538 & 2819 & 2900 & 2921 & 2886 & 2949 \\
\hline 2 & 2568 & 2509 & 2931 & 2821 & 2840 & 2931 & 2968 \\
\hline 3 & 2501 & 2692 & 2929 & 2818 & 2982 & 2933 & 2812 \\
\hline 4 & 2513 & 2577 & 2779 & 2984 & 2893 & 2811 & 2869 \\
\hline 5 & 2502 & & & & & & \\
\hline
\end{tabular}


Procedia of Engineering and Life Science Vol. 1. No. 2 June 2021

Seminar Nasional \& Call Paper Fakultas Sains dan Teknologi (SENASAINS $2^{\text {nd }}$ )

Universitas Muhammadiyah Sidoarjo

\section{Data Harga Jual}

Data diatas akan diuji dengan beberapa metode peramalan untuk mengetahui penjualan pada bulan berikutnya yang paling optimum. Metode yang dipakai adalah Moving Average, Eksponensial Smoothing, dan Newsboy.

Tabel 2 Data Harga Jual

\begin{tabular}{|l|l|}
\hline Harga Beli (c) & $11000 / \mathrm{kg}$ \\
\hline Harga Jual 7 pagi (s) & $15000 / \mathrm{kg}$ \\
\hline Harga Jual 8 pagi (x) & $12500 / \mathrm{kg}$ \\
\hline Harga Jual 9 pagi (v) & $10000 / \mathrm{kg}$ \\
\hline
\end{tabular}

Data harga jual diatas adalah data sekunder untuk metode peramalan Newsboy.

\section{B. Pengolahan Data}

Pola data

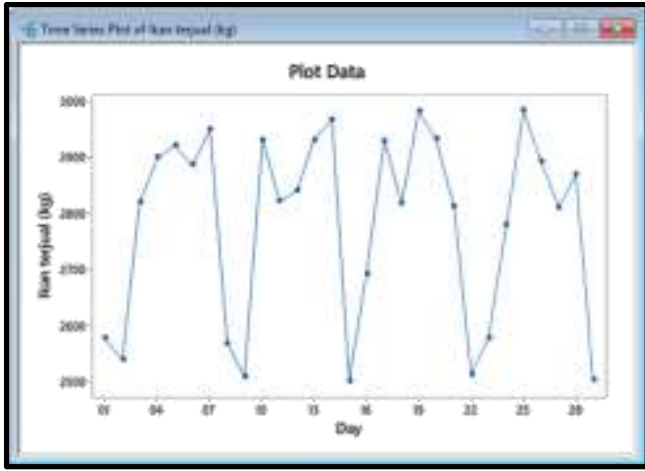

Gambar 2 Pola Data

Berdasarkan dari gambar diatas dapat diketahui bahwa pola data tersebut merupakan pola data musiman, karena di setiap 3 data ada peningkatan dan mengalami penurunan dan peningkatan yang signifikan dalam waktu tertentu.

Trend Analysis

Setelah didapatkan jenis pola data tersebut, maka langkah selanjutnya yang dilakukan adalah melakukan peramalan.

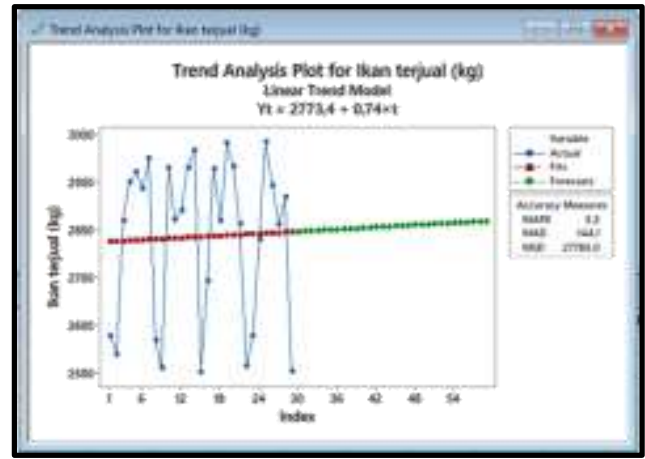

Gambar 3 Trend Analysis

Dari gambar di atas trend yang didapat bahwa data bersifat stabil karena sedikit peningkatan.

Single Moving Average

Metode single moving average merupakan salah satu metode peramalan yang digunakan apabila data pada masa lalu tidak mempunyai faktor musiman [5]. Berikut hasil pengolahan menggunakan software. 
Procedia of Engineering and Life Science Vol. 1. No. 2 June 2021

Seminar Nasional \& Call Paper Fakultas Sains dan Teknologi (SENASAINS $2^{\text {nd }}$ )

Universitas Muhammadiyah Sidoarjo

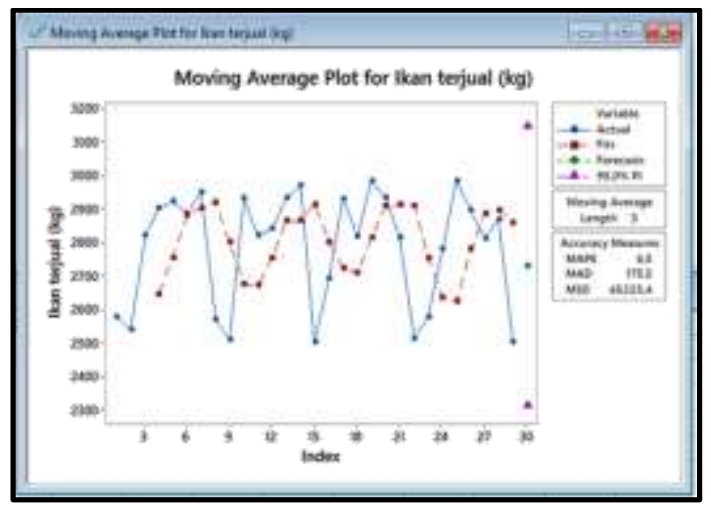

Gambar 4 Single Moving Average

Salah satu contoh perhitungan manual dari metode ini adalah sebagai berikut:

$$
\begin{array}{ll}
\hat{\mathrm{Y} t} \mathrm{t} & =\frac{\mathrm{Yt}+\mathrm{Yt}-1+\ldots+\mathrm{Yt}-\mathrm{n}+1}{\mathrm{~m}} \\
\text { Peramalan hari ke 4 } & =\frac{2577+2538+2819}{3} \\
& =2644,7 \\
\text { MSE hari ke 4 } & =(\mathrm{f}-\mathrm{a}) 2 \\
& =(2644,7-2900) 2 \\
& =65195,1 \\
& =\sum_{\mathrm{i}=1}^{\mathrm{n}} \frac{\mathrm{ei}^{2}}{\mathrm{n}} \\
\text { MSE Total } & =1175861,4 / 29 \\
& =40546,9
\end{array}
$$

Berdasarkan data tersebut dapat diketahui hasil peramalan untuk hari ke 40 adalah 2675,7 kilogram dengan batas bawah (lower) sebesar 2501 kilogram dan batas atas (upper) 2984 kilogram. Namun demikian, peramalan single moving average tidak dapat digunakan untuk jangka panjang karena perhitungan terlalu besar. Perhitungan kesalahan peramalan secara manual dinyatakan dengan nilai MSE sebesar 40546,9.

\section{Single Exponential Smoothing}

Metode single exponential smoothing adalah salah satu meode peramalan pada nilai $t+1$ yang adalah nilai aktual pada periode $t$ ditambah dengan penyesuaian yang berasal dari nilai kesalahan pada periode ini [6]. Exponential smoothing metode ini digunakan untuk peramalan jangka pendek, mengasumsikan bahwa data berfluktuasi di sekitar nilai mean yang tetap [7]. Suatu prosedur yang mengulang perhitungan secara terus menerus yang menggunakan data terbaru [8]. Perbedaan nilai aktual data yang signifikan maka nilai alpha yang digunakan dalam perhitungan manual adalah sebesar 0,1. Berikut hasil analisa dan perhitungan dengan menggunakan aplikasi minitab. 
Procedia of Engineering and Life Science Vol. 1. No. 2 June 2021

Seminar Nasional \& Call Paper Fakultas Sains dan Teknologi (SENASAINS $2^{\text {nd }}$ )

Universitas Muhammadiyah Sidoarjo

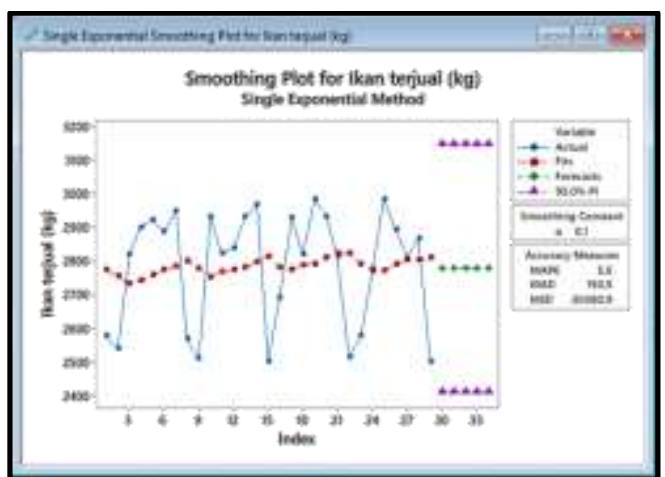

Gambar 4 Single Exponential Smoothing

Diketahui jumlah persediaan ikan untuk hari Senin sampai Jumat sebanyak 3000 kilogram, untuk hari Sabtu dan Minggu sebanyak 2700 kilogram. Berikut hasil perhitungan manual peramalan dengan menggunakan metode single eksponensial smoothing.

$$
\begin{array}{ll}
\hat{\mathrm{Y}} \mathrm{t}+1 & =\mathrm{Yt} \alpha+(1-\alpha) \hat{\mathrm{Y}} \mathrm{t} \\
\mathrm{F} 2 & \\
& =2538 \times 0,1+(0,9 \times 2577) \\
& =2573,1
\end{array}
$$

MSE hari ke $2=(f-a) 2$

$$
\begin{aligned}
& =(2538-2573,1) 2 \\
& =1232,0 \\
& =\sum_{\mathrm{i}=1}^{\mathrm{n}} \frac{\mathrm{ei}^{2}}{\mathrm{n}} \\
& =921696,6 / 29 \\
& =31782,6
\end{aligned}
$$$$
\text { MSE }
$$

Berdasarkan dari data tersebut didapatkan nilai MSE sebesar 83,89. Semakin kecil nilai MSE maka semakin akurat peramalan yang dilakukan. Dari kedua peramalan diatas, nilai MSE dari peramalan Single Eksponensial Smoothing lebih besar dari pada nilai MSE dengan metode Single Moving Average.

\section{Newsboy}

Metode newsboy biasa digunakan untuk mengoptimalisasikan penjualan dengan cara menjual barang yang tidak laku dengan harga miring dikarenakan barang yang dijual mudah rusak atau karena faktor lain [9]. Berikut perhitungan newsboy secara manual.

$$
\begin{array}{ll}
\text { S Sabtu } & =\frac{\sqrt{\sum_{\mathrm{i}=1}^{\mathrm{n}}(\mathrm{xi}-\overline{\mathrm{x}})^{2}}}{\mathrm{n}-1} \\
& =\sqrt{\frac{(2577-2532,2)^{2}}{5-1}} \\
& =\sqrt{\frac{2007,04}{4}} \\
& =\sqrt{501,76} \\
& =22,4 \\
\text { qopt } & =\mu+\sigma \mathrm{Z} \\
\text { Co } & =\mathrm{c}-\mathrm{v}
\end{array}
$$


Procedia of Engineering and Life Science Vol. 1. No. 2 June 2021

Seminar Nasional \& Call Paper Fakultas Sains dan Teknologi (SENASAINS 2nd)

Universitas Muhammadiyah Sidoarjo

$$
\begin{aligned}
& =11000-10000=1000 \\
\mathrm{Cu} & =\mathrm{s}-\mathrm{c} \\
& =15000-11000 \\
& =4000 \\
\mathrm{Z} & =\mathrm{Cu} /(\mathrm{Cu}+\mathrm{Co}) \\
& =4000 /(4000+1000)=0.8
\end{aligned}
$$

qopt Hari ke $1=2577+22,4(0,8)=2594,9$

MSE hari ke $1=(f-d) 2$

$$
\begin{aligned}
& =(2594,9-2577) 2 \\
& =321,1 \\
& =\sum_{\mathrm{i}=1}^{\mathrm{n}} \frac{\mathrm{ei}^{2}}{\mathrm{n}} \\
& =552014 / 29 \\
& =19035,0
\end{aligned}
$$

MSE

Berdasarkan perhitungan menggunakan metode peramalan Newsboy didapatkan nilai MSE sebesar 19035,0. Hasil perhitungan dari metode-metode tersebut akan dibandingkan nilai MSE yang paling kecil.

\section{Perbandingan Nilai MSE}

Berikut adalah perbandingan nilai MSE dari tiga metode peramalan:

Tabel 3 Perbandinga Nilai MSE

\begin{tabular}{|c|l|c|}
\hline No & \multicolumn{1}{|c|}{ Metode Peramalan } & MSE \\
\hline 1 & Single Moving Average & 40546,9 \\
\hline 2 & Single Eksponensial Smoothing & 31782,6 \\
\hline 3 & Newsboy & 19035,0 \\
\hline
\end{tabular}

Dari tabel di atas dapat ditarik kesimpulan bahwa nilai MSE terkecil merupakan peramalan terbaik karena memiliki tingkat error paling rendah.

\section{Moving Range Chart}

Setelah mendapatkan metode peramalan yang sesuai, maka hal yang dilakukan selanjutnya adalah melakukan uji verifikasi. Uji verifikasi dalam penelitian ini menggunakan peta Moving Range Chart (MRC). Peta tersebut digunakan untuk membandingkan data aktual dengan data hasil peramalan [10].

Berikut salah satu contoh perhitungan manual MRC.

$$
\begin{aligned}
\operatorname{MRi} & =\left|\left(\hat{y}_{t}-y_{t}\right)-\left(\hat{y}_{t-1}-y_{t-1}\right)\right| \\
& =|(2631-2594,9)-(2638-2556,9)| \\
& =36,1-81,5 \\
& =-45,6
\end{aligned}
$$

Selanjutnya akan ditetapkan BKA dan BKB dari sebaran data. BKA dan BKB adalah alat yang digunakan untuk mengukur apakah ada data yang keluar batas atau tidak.

$$
\begin{aligned}
\text { MR } & =\sum \frac{M R}{n-1} \\
& =(1842,5 /(31-1))
\end{aligned}
$$


Procedia of Engineering and Life Science Vol. 1. No. 2 June 2021

Seminar Nasional \& Call Paper Fakultas Sains dan Teknologi (SENASAINS $2^{\text {nd }}$ )

Universitas Muhammadiyah Sidoarjo

$$
=61,4
$$

$$
\begin{aligned}
\text { BKA/UCL } & =2.66 \mathrm{MR} \\
& =2.66 * 61,4 \\
& =163,4 \\
& =2 / 3 * 2.66 \mathrm{MR} \\
& =108,9 \\
& =1 / 3 * 2.66 \mathrm{MR} \\
& =54,5 \\
\text { BKB/LCL } & =-2.66 \mathrm{MR} \\
& =2.66 * 3,9 \\
& =-163,4 \\
& =-2 / 3 * 2.66 \mathrm{MR} \\
& =-108,9 \\
& =-1 / 3 * 2.66 \mathrm{MR} \\
& =-54,5
\end{aligned}
$$

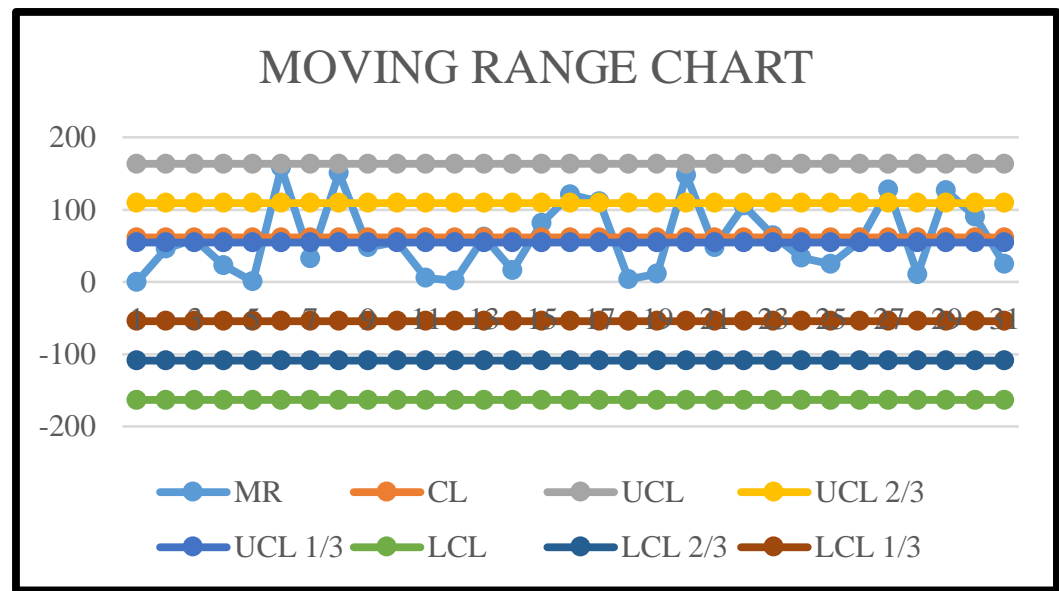

Gambar 5 Moving Range Chart

Berdasarkan pada grafik di atas tidak ada data yang keluar dari BKA maupun BKB, maka data yang dipakai dapat digunakan untuk proses selanjutnya.

\section{Rentang Penjualan Optimum}

Perhitungan rentang optimum dilakukan untuk mendapatkan rentang peluang kumulatif optimum dan dari peluang tersebut didapatkan jumlah persediaan optimum. Berikut adalah perhitungan rentang optimum secara manual.

$$
\begin{aligned}
& \mathrm{F}(\mathrm{X} \leq \mathrm{Q} 0-1) \leq \mathrm{Cu} /(\mathrm{Co}+\mathrm{Cu}) \leq \mathrm{F}(\mathrm{X} \leq \mathrm{Q} 0) \\
& \text { Q0 } \quad=\text { forecast newsboy } \\
& \text { Q0 29 }=2744
\end{aligned}
$$

Sehingga didapatkan nilai rentang optimal hari Rabu (X Rabu) 
Procedia of Engineering and Life Science Vol. 1. No. 2 June 2021

Seminar Nasional \& Call Paper Fakultas Sains dan Teknologi (SENASAINS $2^{\text {nd }}$ )

Universitas Muhammadiyah Sidoarjo

$\mathrm{F}(\mathrm{X}$ Rabu $\quad=2631-1) \leq \mathrm{Cu} /(\mathrm{Co}+\mathrm{Cu}) \leq \mathrm{F}(\mathrm{X}=2631)$

Ekspektasi Keuntungan dan Ekspektasi Resiko

Setelah melakukan uji verifikasi metode peramalan maka langkah selanjutnya adalah melakukan perhitungan ekspektasi keuntungan dan ekspektasi resiko. Perhitungan ekspektasi keuntungan menggunakan persamaan sebagai berikut:

$$
E_{z}(Q)=(s-c) Q-(s-v) \sum_{x=0}^{Q}(Q-x) P(x)
$$

Gambar 6 Rumus Persamaan Ekspektasi Resiko

Ekspektasi keuntungan hari Sabtu (01/03/2020) adalah sebagai berikut:

$$
\begin{aligned}
\mathrm{c} & =11000 \\
\mathrm{v} & =10000 \\
\mathrm{~s} & =15000 \\
\mathrm{Q} & =2631 \\
\mathrm{x} & =2594,9 \\
\mathrm{E} \Pi \quad & =(\mathrm{s}-\mathrm{c}) \mathrm{Q}-(\mathrm{s}-\mathrm{v}) \Sigma(\mathrm{Q}-\mathrm{x}) \mathrm{P}(\mathrm{x}) \\
& =4000.2631-5000 .(2631-2594,9) \\
& =10.524 .000-180.500 \\
& =10.344 .500
\end{aligned}
$$

Setelah melakukan perhitungan ekspektasi keuntungan, maka langkah selanjutnya adalah melakukan perhitungan ekspektasi resiko hari Sabtu (01/03/2020) menggunakan persamaan sebagai berikut:

$$
V_{n}(\varphi)-(x-v)^{2}\left\{2 Q \sum_{x=0}^{0} P(x)-2 \sum_{x=0}^{0} x(Q-x) P(x)-\left[\sum_{x=0}^{Q}(Q-x) P(x)\right]\right\}
$$

Gambar 7 Rumus Persamaan Ekspektasi Resiko

Sehingga didapatkan ekspektasi resiko pada hari Sabtu (01/03/2020) adalah sebagai berikut:

$$
\begin{array}{ll}
\operatorname{V\Pi (}(\mathrm{Q}) & =(15000-10000) 2((2.2631 .(2631-2594,9)-(2 .(2594,9) .(2631-2594,9)-(2631-2594,9) 2) \\
& =50002(189.958,2-187.351,78-1.303,21) \\
& =32.580 .250 .000 \\
& =\sqrt{32.580 .250 .000} \\
& =180.500
\end{array}
$$

Setelah melakukan perhitungan ekspektasi keuntungan dengan nilai 10.344 .500 dan ekspektasi resiko didapatkan dengan nilai 180.500 maka bisa disimpulkan bahwa ekspektasi keuntungan lebih besar dan ekspektasi resiko lebih bisa di minimalkan, maka langkah selanjutnya adalah menganalisa hasil dari pengolahan data tersebut.

\section{Analisa}

Hasil yang didapatkan dari total MSE terkecil dari tabel 4.6 adalah metode peramalan Neswboy adalah metode terbaik dalam meramalkan penjualan ikan pada penelitian ini. Hasil perhitungan moving range chart tidak ada data yang melebihi BKA maupun BKB yang artinya data layak untuk diolah ke pengolahan selanjutnya. Pada hasil 
Procedia of Engineering and Life Science Vol. 1. No. 2 June 2021

Seminar Nasional \& Call Paper Fakultas Sains dan Teknologi (SENASAINS 2nd)

Universitas Muhammadiyah Sidoarjo

ekspektasi keuntungan terjadi keuntungan terbesar pada hari Jumat (13/03/2020) sebesar 12.508.000 rupiah, sedangkan untuk ekspektasi resiko terbesar terjadi pada hari Sabtu (28/03/2020) sebesar 1.249.500 rupiah.

\section{KESIMPULAN}

Diketahui jumlah persediaan ikan untuk hari senin sampai jumat sebanyak $3000 \mathrm{~kg}$, perhitungan ini berdasarkan hasil dari pola data, trend analysis dan rata-rata ikan yang terjual bisa disimpulkan bahwa persediaan dihari seninjum'at dapat menghasilkan keuntungan yang optimum.

Saran yang dapat diberikan dari penelitian ini yaitu dalam menentukan jumlah persediaan diharapkan penjual ikan agar konsisten menyediakan persediaan yang dapat menghasilkan keuntungan yang optimum. Dan semoga hasil dari penelitian ini diharapkan bisa di implementasikan oleh penjual-penjual ikan agar kedepannya bisa mengoptimalkan keuntungan yang didapatkan.

\section{REFERENSI}

[1] Hasanah, Hisyam. "Teknik-Teknik Observasi”, Jurnal at-taqaddum. Vol 8, pp. 22-46, Juli. 2016.

[2] Ismail, Bagus Adhi Wicaksana. Erni Suparti. “Optimisasi Jumlah Produksi Menggunakan Model Newsboy dan Perencanaan Pengendalian Bahan Baku Menggunakan Material Requirement Planning (MRP)", Prozima. Vol 2, pp 88-99, Desember 2018.

[3] Khosiah, Hajrah, Syafril. "Persepsi Masyarakat Terhadap Rencana Pemerintah Membuka Area Pertambangan Emas di Desa Sumi Kecamatan Lambu Kabupaten Bima”, JISIP. Vol 1, pp, 141-149, November. 2017

[4] Bamban, Ribangun Jakaria. Chylen Setiyo Rini. "Analisis Supply Chain Manajemen Guna Optimalisasi Distribusi Ikan Bandeng”, pp 429-434, Februri. 2017

[5] Prasanti, Ditha. "Penggunaan Media Komunikasi Bagi Remaja Perempuan Dalam Pencarian Informasi Kesehatan”, Jurnal Lontar. Vol 6, pp, 13-21, Juni. 2018.

[6] Hudaningsih,Nurul, dkk. "Perbandingan Peramalan Penjualan Produk Aknil PT. Sunthi Sepuri mengguanakan Metode Single Moving Average Dan Single Exponential Smooting” Jurnal JINTEKS. Vol 2, pp, 15-22, Februari. 2020.

[7] Sri, Kadek Krisna Dewi, Kadek Rai Suwena. “Analisis Peramalan Tingkat Jumlah Tamu Menginap Menggunakan Metode Single Exponential Smoothing Di Villa X Di Desa Gobleg, Kabupaten Buleleng Tahun 2018”, Jurnal Pendidikan Ekonomi Undiksha. Vol 9, pp, 335-344, 2017.

[8] Mingsi, Yoszi Anaperta. "Evaluasi Keserasian (Match Factor) Alat Muat Dan Alat Angkut Dengan Metode Control Chart (Peta Kendali) Pada Aktivitas Penambangan Di Pit X PT Y”, Jurnal Teknologi Informasi dan Pendidikan

[9] Rachman, Rizal. "Penerapan Metode Moving Average dan Exponential Smoothing Pada Peramalan Produksi Industri Garment”, Jurnal Informatika. Vol.5, pp.211-220, No.1. September. 2018.

[10] Abdul Jabbar, Wari Ammar. Frida Utami, Silvia. Hudaningsih, Nurul. "Perabandingan Peramalan Penjualan Produk Aknil PT. SunthiSepuri Menggunakan Metode Single Moving Average Dan Single Exponential Smoothing”. Jurnal JINTEKS. Vol 2. No. 1. ISNN: 2686-3359. Februari 2020. 